Journal of Animal and Veterinary Advances 9 (19): 2552-2560, 2010

ISSN: $1680-5593$

(C) Medwell Journals, 2010

\title{
Persistence of the Inhabitants of a Region to Raise Pure Hair Goats: A Case Study on the Province of Burdur in Turkey
}

\author{
${ }^{1}$ Sultan Bekiroglu and ${ }^{2}$ Ahmet Tolunay \\ ${ }^{1}$ Faculty of Forestry, Istanbul University, 34473 Bahcekoy, Istanbul, Turkey \\ ${ }^{2}$ Faculty of Forestry, Suleyman Demirel University, 32260 Cunur, Isparta, Turkey
}

\begin{abstract}
The objective of this study is to describe the relations between the social, economic and demographic properties of the household heads raising pure hair goats in the province of Burdur where pure hair goats are raised traditionally in Turkey and designate the underlying reasons for the persistence in raising pure hair goats despite all legal restraints. The study material is composed of the data from the surveys conducted with 786 household heads raising pure hair goats in 10 municipal districts of Burdur. The surveys have been conducted between 2005-2007 by the Regional Directorate of Forestry of Isparta. The responses on the surveys composed of 18 questions have been digitalized and transferred to a computer via Microsoft Excel. The statistical analyses have been performed by using the program Statistical Package for Social Sciences version 11.0 upon utilizing non-parametric analysis methods. The statistical test results have been tested at a significance level of $5 \%$ $(\mathrm{p}<0.05)$. Furthermore, the socio-economic, demographic and traditional properties of household heads raising pure hair goats have been described with the help of tables and graphics. It was demonstrated that there is conformity among the household heads raising pure hair goats in 10 municipal districts of Burdur in terms of the level of education, manner of utilizing pure hair goat milk, land ownership, migration being a shepherd, types of public loan demands and persistence in raising pure hair goats and that there is no conformity in terms of the amount of pure hair goats raised, the income obtained from pure hair goats and other resources, duration of migration, ownership of dry and irrigated land. Furthermore, a relation was detected between the number of pure hair goats raised and the number of family members in 2 provinces; between the number of pure hair goats and the income gained from goats in 4 municipal districts; between the number of pure hair goats and the amount of irrigated agricultural land in 1 municipal district; the number of pure hair goats and utilization of goat milk in 1 municipal district. Descriptive analyses have demonstrated that household heads with a low education level, low income and no agricultural land to use will refuse to utilize the public loans proposed for earning their living via other economic activities and will continue raising pure hair goats.
\end{abstract}

Key words: Pure hair goat, rural development, rural poverty, traditional breeding, Burdur province, Turkey

\section{INTRODUCTION}

Production in the economic sense increases the amount and the degree of efficacy upon using the following factors: nature, manpower, capital and enterprise. Yet, production is generally conducted by using abundant and cheap production factors (Ertek, 2008). Similarly, forest villagers produce goods to fulfill their needs by using the resources around them.

Forest resources are facing a very high number of threats in many countries. For instance, people living within and adjacent to forests are perceived as a threat risk. Many institutes and organizations strive to reduce the degree of this threat or try to eliminate it completely (Gilmour and Fisher, 1991). In Turkey, it is claimed that pure hair goat breeding which is traditionally performed in the forest villages and is one of the main means of living of the people, harms the forests in the country. Thus, the General Directorate of Forestry (GDF) which is responsible for operating and protecting the forests, tries to reduce the number of pure hair goats in the region and steer the locals to other sources of income (Avci, 2005).

The areas where pure hair goat breeding is conducted are forest areas according to laws. In Article 19 of the Forest Law No. 6831, it is stipulated that it is forbidden to take any type of animal into public forests whereas in Article 21 of the said Law it is stated that taking animals from outside into the pastures of public forests, collectively or in herds, so as to graze them shall be subjected to the permission of the forestry administration according to the plans to be drawn up.

Corresponding Author: Sultan Bekiroglu, Faculty of Forestry, Istanbul University, 34473 Bahcekoy, Istanbul, Turkey 
The Grazing regulation prepared for enforcing these articles has forbidden pure hair goat grazing within public forests. On Article 95 of the said Law, it is stipulated that: those who take animals inside forests without any permission, in violation of the provisions of this law shall be subjected to imprisonment of not $<1$ month and a fine. Based on the provisions of this law, the Forestry administration files lawsuits against people who graze pure hair goats in public forests. These persons regarded as guilty by legal authorities are subjected to fines and imprisonment (GFD, 1984). Widely used breeds in goat raising in Turkey are pure hair goats and angora goats. Among these, pure hair goats (Capra hircus L.) constitute the breed raised at the highest rate with $96 \%$ (Ozder, 1997). The regions where pure hair goat production is widely performed are the Aegean, Mediterranean and Southeast Anatolian Regions. The people living in these regions have been raising pure hair goats in the upper basins since centuries (Ocak et al., 2007). In addition to being a production system, pure hair goat raising is also the symbol of a cultural value for these people (Geray and Ozden, 2003). There are similarities between the borders of the regions where pure hair goats are bred and natural distribution borders of some types of trees and shrubs within the Mediterranean scrub vegetation. This similarity is demonstrated clearly in Kermes Oak (Quercus coccifera L.) and Boz Pirnal
Oak (Qercus aucheri Jaub and Spach.) types. Both types of shrubs are woody types, the leaves of which are eaten fondly by the pure hair goats. Pure hair goats have selected as their habitat the natural distribution area of these two types of shrubs (Tolunay et al., 2009). The measures adopted against grazing of goats in forests are technical as well as social, economic and administrative in nature. It is necessary to settle the opposite relation between forestry and goat raising (Tolunay and Ayhan, 2010). The objective of this study is to describe the socioeconomic and demographic properties of pure hair goat breeders, adopted by the locals of Burdur but regarded as a major threat by the administrators of forest resources in Turkey, to designate the relations between the referred properties and also to determine the reasons for the persistence in actively raising pure hair goats in this region.

\section{MATERIALS AND METHODS}

Study area: There are 11 municipal districts in the province of Burdur, located in the mediterranean region of Turkey, namely: Yesilova, Aglasun, Altinyayla, Bucak, Cavdir, Celtikci, Karamanli, Kemer, Merkez and Tefenni. Among these municipal districts, 67 forest villages raising pure hair goats in all municipal districts except Yesilova have been taken as basis in this study (Fig. 1).

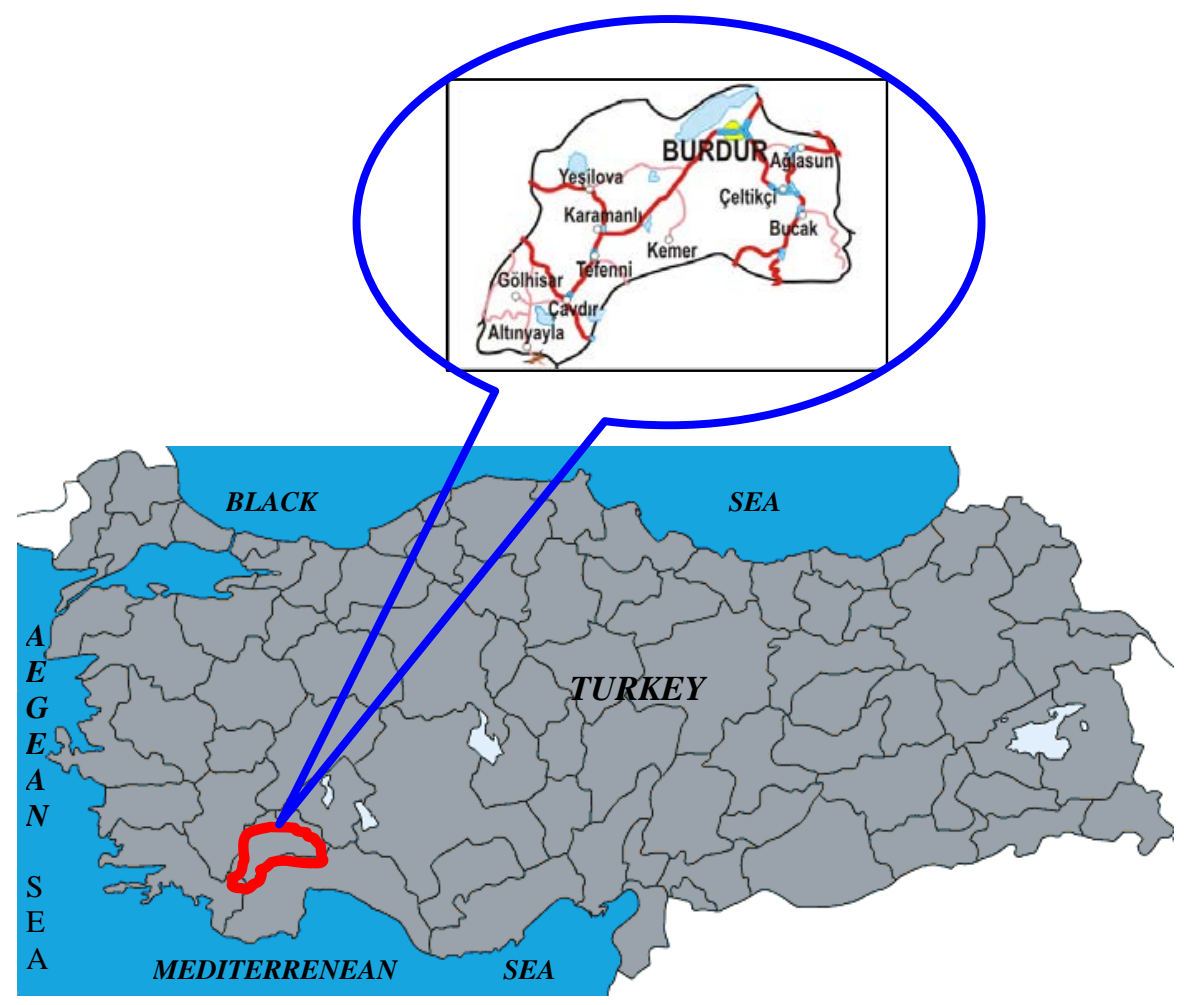

Fig. 1: Study area 
Table 1: Distribution of settlement units, population, pure hair goats, forests and agricultural land to households in forest villages as of 2005 (GDFVR, 2010) Forest areas

Forest villages

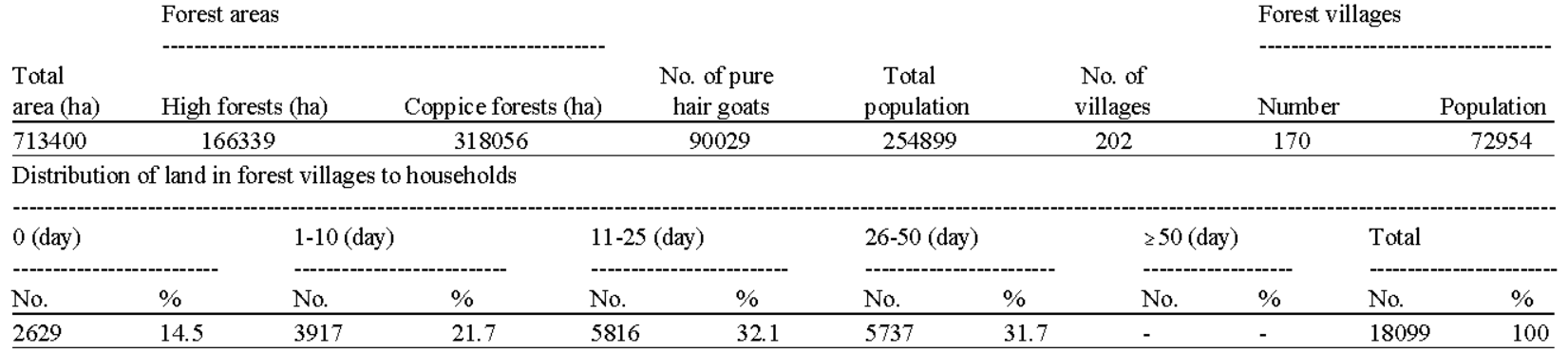

Table 2: Variables used in the research

\begin{tabular}{ll}
\hline Groups & Variables \\
\hline Group 1: Social & Education level of household head (X1), Number of dependent persons (X2) \\
Group 2: Economic & Income obtained from goats (X3), Income obtained from other activities (X4), Income obtained from \\
& goats (X5), Total Income(X6) \\
Group 3: Pure hair goats & Number of female pure hair goats (X7), Number of male pure hair goats (X8), Number of male pure \\
& hair goats (X9) \\
Group 4: Traditional and economic & Migration status in raising pure hair goats (X10), Period of migration (X11), Period of stay ing in \\
& a settlement area (X12), Being a shepherd (X16), Type of public loan requested (X17), Persistence \\
in raising pure hair goats (X18) & Land ownership (X13), Irrigated land ownership(X14), Dry agricultural land ownership (X15) \\
\hline
\end{tabular}

The distribution of settlement units, population, pure hair goats, forests and agricultural land to the households in the forest villages in the province of Burdur as of 2005 are shows in Table 1. In the province of Burdur, $60.6 \%$ is highland, $2.7 \%$ is upland, $19 \%$ is lowland and $17.6 \%$ is rugged terrain. The general average elevation of the province is $1.000 \mathrm{~m}$.

Although, the population of the province drops by $0.2 \%$ annually due to migration, a population explosion has been occurring in recent years. The share of rural population in the overall population is $41 \%$ (TSI, 2010 ; SPO., 1996). The province of Burdur is one of the regions raising the highest rate of pure hair goats in Turkey. It is reported that the rate of pure hair goats $\mathrm{km}^{2}$ was $>100$ in the province of Burdur in the $70 \mathrm{~s}$.

The study material is composed of the surveys conducted with household heads raising pure hair goats in 67 forest villages in 10 municipal districts of the province of Burdur. The survey comprises all families raising pure hair goats in 67 forest villages. Therefore, it is possible to say that the whole area has been observed. A survey has been conducted with 786 household heads in total by using the face-to-face interview technique in the following municipal districts: 96 in the municipal district of Aglasun, 72 in the municipal district of Altinyayla, 308 in the municipal district of Bucak, 63 in the municipal district of Cavdir, 15 in the municipal district of Celtikci, 63 in the municipal district of Golhisar, 5 in the municipal district of Karamanli, 5 in the municipal district of Kemer, 121 in the municipal district Merkez (Central district) and 38 in the municipal district of Tefenni. The survey forms contain 18 questions regarding the socio-economic, demographic properties and pure hair goats of household heads raising pure hair goats. These questions have been designated as variables indicated in Table 2 in this study.

The conformity among the household heads raising pure hair goats in 10 municipal districts of the province of Burdur in terms of the variables in Table 2 have been determined with Chi-square conformity tests and the relations between the variables have been determined with the Chi-Square independence tests.

Moreover, the similarities and differences between the municipal districts in terms of variables have been described with the help of tables and graphics upon calculating the percentages of the frequencies observed.

Statistical analyses: The conformity level tests of Chisquare tests which may be used for various purposes are used for determining the presence or absence of relations and/or whether two variables are independent or not (Altunisik et al., 2005). In the Chi-square conformity tests in this study, the following hypotheses have been established:

$\mathrm{H}_{0}$ : There is conformity among the members of the community in terms of variable $\mathrm{X}_{\mathrm{i}}(\mathrm{i}: 1, . .18)$

$\mathrm{H}_{1}$ : There is no conformity among the members of the relevant community in terms of variable $\mathrm{Xi}(\mathrm{i}: 1, \ldots 18)$ 
Whereas, the following hypotheses have been established in the independence tests:

$\mathrm{H}_{0}$ : There is independence (difference) between the two variables in the relevant community

$\mathrm{H}_{1}$ : There is no independence (difference) between the two variables in the relevant community

The cross tabulations in the form of $2 \times 2$ in the Chisquare independence tests display a special condition. When one of the cells in these tables holds a value $<5$, it is necessary to apply the Yates correction factor on the analysis results (Ozdamar, 2002).

However, if all of the values in the cells of $2 \times 2$ tables are $>5$, the independence test is performed with the Pearson Chi-square test. Most the cross tables in this study are in $2 \times 2$ form and have been prepared when the values in the cells of cross tables constituting the statistical testing are $>5$. Therefore, Pearson Chisquare tests have been applied in this study. In the statistical analyses, the SPSS 11.0 (Statistical Package for Social Sciences for Windows 11.0) program has been used and the test results have been tested at a significance level of 5\%. Furthermore, the frequencies and percentages of variables in the municipal districts have been tabulated with Excel and drawn graphically.

\section{RESULTS AND DISCUSSION}

The Chi-square conformity test results of 18 variables in 10 municipal districts in the study area are shown in Table 3 . According to Table 3 , there is conformity among

Table 3: Results of Chi-square conformity test statistics

\begin{tabular}{|c|c|c|c|c|c|c|c|c|c|c|}
\hline \multicolumn{2}{|c|}{$\begin{array}{l}\text { Name of } \\
\text { municipal district }\end{array}$} & \multirow{2}{*}{$\frac{X 1}{61.1800}$} & \multirow{2}{*}{$\frac{X 2}{11.430}$} & \multirow{2}{*}{$\begin{array}{r}\mathrm{X} 3 \\
-\end{array}$} & \multirow{2}{*}{$\frac{X 4}{18716.3}$} & \multirow{2}{*}{$\mathrm{X5}$} & \multirow{2}{*}{$\frac{X 6}{1783.2}$} & \multirow{2}{*}{$\frac{X 7}{2495.9}$} & \multirow{2}{*}{$\frac{X 8}{2721.5}$} & \multirow{2}{*}{$\frac{X 9}{0.497}$} \\
\hline Aglasun & $\chi^{2}$ & & & & & & & & & \\
\hline $\mathrm{n}=96$ & $\tilde{\mathrm{p}}$ & 0.9970 & 1.000 & - & $0.000^{*}$ & - & $0.000^{*}$ & $0.000^{*}$ & $0.000^{*}$ & 1.000 \\
\hline Altinyayla & $x^{2}$ & 34.8900 & 0.000 & 41032.7 & - & 41033 & 5669.2 & 740.374 & 6163.6 & 0.000 \\
\hline $\mathrm{n}=72$ & $\mathrm{p}$ & 1.0000 & 1.000 & $0.000^{*}$ & - & $0.000^{*}$ & $0.000^{*}$ & $0.000^{*}$ & $0.000^{*}$ & 1.000 \\
\hline Bucak & $\chi^{2}$ & 218.5500 & 11.690 & - & - & - & 14626.40 & 12233.1 & 15885.3 & 151.170 \\
\hline $\mathrm{n}=308$ & $\mathrm{p}$ & 1.0000 & 1.000 & - & - & - & $0.000^{*}$ & $0.000^{*}$ & $0.000^{*}$ & 1.000 \\
\hline Cavdir & $\chi^{2}$ & 35.2600 & 1.298 & - & 10065.1 & - & 6950.87 & 1018.35 & 6991.72 & 0.000 \\
\hline $\mathrm{n}=63$ & $\mathrm{p}$ & 0.9980 & 1.000 & - & $0.000^{*}$ & - & $0.000^{*}$ & $0.000^{*}$ & $0.000^{*}$ & 1.000 \\
\hline Celtikci & $\chi^{2}$ & 6.0000 & 0.000 & 123736.8 & - & 123737 & 886.370 & $104.449^{*}$ & 1008.99 & - \\
\hline $\mathrm{n}=15$ & $\hat{\mathrm{p}}$ & 0.9660 & 1.000 & $0.000^{*}$ & - & $0.000^{*}$ & $0.000^{*}$ & $0.000^{*}$ & $0.000^{*}$ & 1.000 \\
\hline Golhisar & $x^{2}$ & 60.8570 & 0.000 & 252497.9 & 9873.2 & - & 3930.53 & 2376.60 & 4640.13 & 0.984 \\
\hline $\mathrm{n}=63$ & $\hat{\mathrm{p}}$ & 0.5170 & 1.000 & $0.000^{*}$ & $0.000^{*}$ & - & $0.000^{*}$ & $0.000^{*}$ & $0.000^{*}$ & 1.000 \\
\hline Karamanli & $\chi^{2}$ & 0.2110 & 0.941 & 10909.1 & - & 10909 & 314.38 & 61.786 & 352.63 & 0.000 \\
\hline $\mathrm{n}=5$ & $\mathrm{p}$ & 0.9950 & 0.919 & $0.000^{*}$ & - & $0.000^{*}$ & $0.000^{*}$ & $0.000^{*}$ & $0.000^{*}$ & 1.000 \\
\hline Kemer & $\chi^{2}$ & 1.1820 & 0.000 & 37044.9 & - & 37045 & 361.779 & 111.26 & 529.15 & 0.000 \\
\hline $\mathrm{n}=5$ & $\mathrm{p}$ & 0.8810 & 1.000 & $0.000^{*}$ & - & $0.000^{*}$ & $0.000^{*}$ & $0.000^{*}$ & $0.000^{*}$ & 1.000 \\
\hline Merkez & $\chi^{2}$ & 68.3600 & 7.183 & - & 38282.8 & - & 3958.45 & 4071.29 & 4394.55 & 18.350 \\
\hline $\mathrm{n}=121$ & $\hat{\mathrm{p}}$ & 1.0000 & 1.000 & - & $0.000^{*}$ & - & 0.000 & $0.000^{*}$ & 0.000 & 1.000 \\
\hline Tefenni & $x^{2}$ & 17.2000 & 11.630 & - & - & - & 1249.19 & 829.39 & 1439.26 & 0.000 \\
\hline $\mathrm{n}=38$ & $\hat{\mathrm{p}}$ & 0.9980 & 1.000 & - & - & - & $0.000^{*}$ & $0.000^{*}$ & $0.000^{*}$ & 1.000 \\
\hline \multicolumn{2}{|c|}{$\begin{array}{l}\text { Name of } \\
\text { municipal district }\end{array}$} & $\mathrm{X} 10$ & $\mathrm{X} 11$ & $\mathrm{X} 12$ & $\mathrm{X} 13$ & $\mathrm{X} 14$ & $\mathrm{X} 15$ & $\mathrm{X} 16$ & $\mathrm{X} 17$ & $\mathrm{X} 18$ \\
\hline Aglasun & $\chi^{2}$ & 0.000 & - & 0.000 & 11.61 & 359.06 & 1328.6 & 0.000 & 25.092 & 0.989 \\
\hline $\mathrm{n}=96$ & $\hat{\mathrm{p}}$ & 1.000 & - & 1.000 & 1.000 & 0.000 & 0.000 & 1.000 & 1.000 & 1.000 \\
\hline Altinyayla & $\chi^{2}$ & 0.000 & - & 0.000 & 0.000 & 33.600 & - & 0.000 & 3.050 & 12.273 \\
\hline $\mathrm{n}=72$ & $\mathrm{p}$ & 1.000 & - & 1.000 & 1.000 & 1.000 & - & 1.000 & 1.000 & 1.000 \\
\hline Bucak & $\chi^{2}$ & 4.840 & 52.81 & 1693 & 40.59 & 598.12 & 5649.83 & 3.897 & 455.730 & 5421.6 \\
\hline $\mathrm{n}=308$ & $\mathrm{p}$ & 1.000 & $0.000^{*}$ & $0.000^{*}$ & 1.000 & $0.000^{*}$ & $0.000^{*}$ & 1.000 & $0.000^{*}$ & $0.000^{*}$ \\
\hline Cavdir & $\chi^{2}$ & 0.000 & - & 0.000 & 10.361 & 470.48 & - & 0.000 & 0.000 & 0.000 \\
\hline $\mathrm{n}=63$ & $\hat{\mathrm{p}}$ & 1.000 & - & 1.000 & 1.000 & $0.000^{*}$ & - & 1.000 & 1.000 & 1.000 \\
\hline Celtikci & $\chi^{2}$ & 0.000 & - & 0.000 & 2.435 & - & 53.91 & 2.000 & 3.294 & 0.000 \\
\hline $\mathrm{n}=15$ & $\hat{\mathrm{p}}$ & 1.000 & - & 1.000 & 1.000 & - & $0.000^{*}$ & 1.000 & 0.998 & 1.000 \\
\hline Golhisar & $\chi^{2}$ & 4.154 & - & 0.000 & 6.486 & 1040.36 & - & 0.969 & 2.870 & 4.154 \\
\hline $\mathrm{n}=63$ & $\mathrm{p}$ & 1.000 & - & 1.000 & 1.000 & $0.000^{*}$ & - & 1.000 & 1.000 & $0.042^{*}$ \\
\hline Karamanli & $x^{2}$ & 0.000 & - & 0.000 & 0.000 & - & - & 0.000 & 0.000 & 0.000 \\
\hline $\mathrm{n}=5$ & $\mathrm{p}$ & 1.000 & - & 1.000 & 1.000 & - & - & 1.000 & 1.000 & 1.000 \\
\hline Kemer & $\chi^{2}$ & 0.000 & - & 0.000 & 0.667 & - & - & 0.000 & 0.214 & 0.000 \\
\hline $\mathrm{n}=5$ & $\hat{\mathrm{p}}$ & 1.000 & - & 1.000 & 0.955 & - & - & 1.000 & 0.995 & 1.000 \\
\hline Merkez & $\chi^{2}$ & 4.603 & 13.50 & 50.48 & 16.286 & 5.696 & 3471.32 & 6.234 & 133.970 & 0.498 \\
\hline $\mathrm{n}=121$ & $\hat{\mathrm{p}}$ & 1.000 & $0.009^{*}$ & 1.000 & 1.000 & 0.127 & $0.000^{*}$ & 1.000 & 0.181 & 1.000 \\
\hline Tefenni & $\chi^{2}$ & 0.000 & - & 0.000 & 0.000 & - & - & 0.000 & 1.284 & 0.000 \\
\hline$\underline{n}=38$ & $\mathrm{p}$ & 1.000 & - & 1.000 & 1.000 & - & - & 1.000 & 1.000 & 1.000 \\
\hline
\end{tabular}

$\mathrm{n}$ : sample size; $\mathrm{p}$ : level of significance; $\chi^{2}$ : Chi-square co-efficient; Individuals are not compliant in terms of variable $\mathrm{X}_{\mathrm{i}}$ (there are differences between individuals) $(\mathrm{p}<0.05)$ 


\begin{tabular}{|c|c|c|c|c|c|c|c|c|c|c|}
\hline \multirow[b]{2}{*}{$\begin{array}{l}\text { Municipal } \\
\text { district }\end{array}$} & \multicolumn{2}{|c|}{ Pearson $\chi^{2}$} & \multicolumn{2}{|c|}{ Likelihood ratio } & \multirow[b]{2}{*}{ df } & \multicolumn{2}{|c|}{ Pearson $\chi^{2}$} & \multicolumn{2}{|c|}{ Likelihood ratio } & \multirow[b]{2}{*}{$\mathrm{df}$} \\
\hline & Value & $\mathrm{p}$ & $\begin{array}{r}\text { Value } \\
\text { x1-X8--. }\end{array}$ & p & & $\begin{array}{l}\text { Value } \\
-\end{array}$ & $p$ & $\begin{array}{l}\text { Value } \\
\text { X3-X8- }\end{array}$ & $\mathrm{p}$ & \\
\hline Aglasun & 2.720 & 0.099 & 2.730 & 0.098 & 1 & 30.79 & $0.000^{*}$ & 32.84 & $0.000^{*}$ & 1 \\
\hline Altinyayla & 12.990 & $0.000^{*}$ & 13.490 & $0.000^{*}$ & 1 & 24.73 & $0.000^{*}$ & 26.47 & $0.000^{*}$ & 1 \\
\hline Bucak & 2.870 & 0.090 & 2.812 & 0.094 & 1 & 78.51 & $0.000^{*}$ & 78.24 & $0.000^{*}$ & 1 \\
\hline Cavdir & 0.466 & 0.495 & 0.461 & 0.497 & 1 & - & - & - & - & - \\
\hline Golhisar & 1.942 & 0.163 & 1.953 & 0.162 & 1 & - & - & - & - & - \\
\hline Merkez & 2.068 & 0.150 & 2.090 & 0.148 & 1 & 33.64 & $0.000^{*}$ & 35.80 & $0.000^{*}$ & 1 \\
\hline Tefenni & 8.341 & 0.004 & 8.453 & 0.004 & 1 & - & - & - & - & - \\
\hline
\end{tabular}

${ }^{1}$ Chi-square test has not been performed in Celtikci, Kemer and Karamanli as $n=5 ; \chi^{2}$ : Chi-Square test statistics; df: degree of freedom; $p$ : level of significance $(5 \%) ;{ }^{*} \mathrm{H}_{1}$; The hypothesis There is no independence between variables has been adopted $(\mathrm{p}<0.05)$

Table 5: Results of Chi square tests ${ }^{1}$

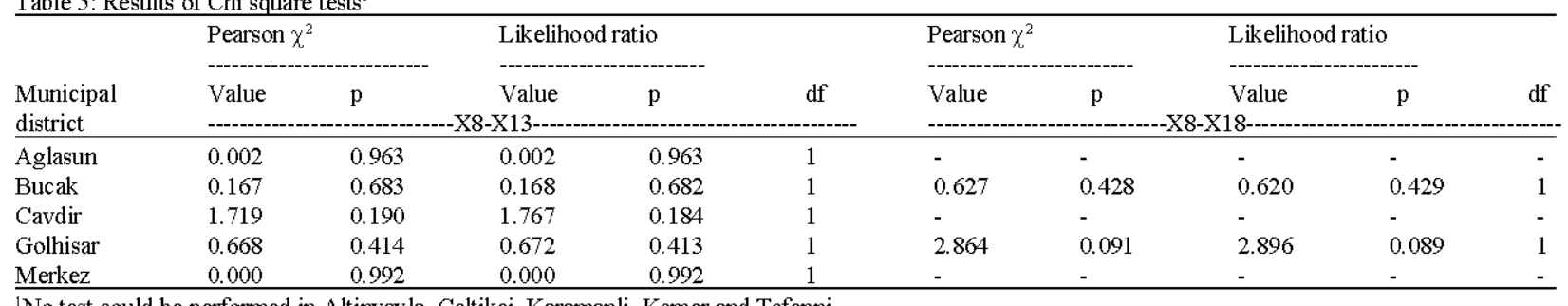

${ }^{1}$ No test could be performed in Altinyayla, Celtikci, Karamanli, Kemer and Tefenni

household heads raising pure hair goats in municipal districts, in terms of the number of dependent persons (X1), education level (X2), manner of utilizing pure hair goat milk (X9), whether migration takes place in raising pure hair goats $(\mathrm{X} 10)$, period of staying in a settlement area (X12), being a shepherd (X16), type of loan to be requested in case he renounces to raise pure hair goats (X17) and whether they are persistent in raising pure hair goats $(\mathrm{X} 18)(\mathrm{p}<0.05)$.

Whereas, there is no conformity among household heads raising pure hair goats in the municipal districts in terms of the other variables $(p>0.05)$. The Chi-square independence test results on the relations between the variables the number of dependent persons (X1) and number of pure hair goats raised (X8), the income obtained from pure hair goats (X3) and the number of pure hair goats raised (X8) in the municipal districts of Aglasun, Altinyayla, Bucak, Cavdir, Golhisar, Merkez and Tefenni have been shown in Table 4. According to Table 4 , there is a relation between the number of dependents that the household head has to take care of and the number of pure hair goats in the municipal districts of Altinyayla and Tefenni and the income obtained from goats and the number of goats raised in the municipal districts of Aglasun, Altinyayla, Bucak and the Merkez ( $<<0.05)$.

The Chi-square independence test results on the relations between the variables the number of pure hair goats raised (X8), being a shepherd (X16), the number of pure hair goats raised (X8) and the persistence in raising pure hair goats (X18) in the municipal districts of
Aglasun, Bucak, Cavdir, Golhisar and Merkez are shown in Table 5. According to Table 5, there is no relation between the number of pure hair goats raised, land ownership and the persistence in raising pure hair goats in the municipal districts of Aglasun, Bucak, Cavdir, Golhisar and Merkez ( $p>0.05)$.

The Chi-square independence test results on the relations between the variables the income obtained from pure hair goats (X3), the persistence in raising pure hair goats (X18), the number of pure hair goats raised (X8), manner of utilization of pure hair goat milk (X9) in the municipal district of Bucak; the number of pure hair goats raised (X8) and the amount of irrigated agricultural land (X14) in the municipal district of Golhisar; the number of dependent persons (X1), the manner of utilizing pure hair goat milk (X9), the number of pure hair goats raised (X8) and the manner of utilizing pure hair goat milk (X9) the municipal district of Merkez are shown in Table 6.

$\mathrm{H}_{1}$ : The hypothesis is that there is no independence between variables has been adopted $(\mathrm{p}<0.05)$

According to Table 6, there is no relation between the number of pure hair goats and the amount of irrigated agricultural land in the municipal district of Golhisar whereas, there is no relation between the number of pure hair goats and the manner of utilizing milk in the municipal district of Merkez $(\mathrm{p}<0.05)$. The distribution of the number of dependent persons that the household heads raising pure hair goats have to take care of is shown in Table 7. In Table 7 , the number of dependent persons that the 
Table 6: Results of Chi square tests

\begin{tabular}{|c|c|c|c|c|c|}
\hline \multirow[b]{2}{*}{ Municipal district } & \multicolumn{2}{|c|}{ Pearson $\chi^{2}$} & \multicolumn{2}{|c|}{ Likelihood ratio } & \multirow[b]{2}{*}{$\mathrm{df}$} \\
\hline & Values & $\mathrm{p}$ & Values & $\mathrm{p}$ & \\
\hline $\mathrm{X3-X18}$ & & & & & \\
\hline $\begin{array}{l}\text { Altinyayla } \\
\text { X8-X9 }\end{array}$ & 1.234 & 0.267 & 1.249 & 0.264 & 1 \\
\hline $\begin{array}{l}\text { Bucak } \\
\text { X8-X14 }\end{array}$ & 3.497 & 0.061 & 3.438 & 0.064 & 1 \\
\hline $\begin{array}{l}\text { Golhisar } \\
\text { X1-X9 }\end{array}$ & 3.888 & $0.049^{*}$ & 0.938 & $0.047^{*}$ & 1 \\
\hline $\begin{array}{l}\text { Merkez } \\
\text { X8-X9 }\end{array}$ & 3.291 & 0.070 & 3.244 & 0.072 & 1 \\
\hline Merkez & 12.249 & $0.000^{*}$ & 12.454 & $0.000^{*}$ & 1 \\
\hline
\end{tabular}

${ }^{*} \mathrm{H}_{1}$; The hypothesis There is no independence between variables has been adopted $(\mathrm{p}<0.05)$

Table 7: Distribution of the number of dependent persons that the household heads raising pure hair goats have to take care of

No. of

\begin{tabular}{|c|c|c|c|c|c|c|c|c|c|c|}
\hline household & Aglasun & Altinyayla & Bucak & Cavdir & Celtikci & Golhisar & Karamanli & Kemer & Merkez & Tefenni \\
\hline 1 & 3.1 & - & 10.7 & 1.6 & - & 3.2 & - & - & 2.5 & - \\
\hline 2 & 25.0 & 37.5 & 24.7 & 7.9 & 6.7 & 12.7 & - & - & 9.1 & 15.8 \\
\hline 3 & 16.6 & 18.1 & 29.5 & 7.9 & 20.0 & 9.5 & 20.0 & 20.0 & 19.8 & 23.7 \\
\hline 4 & 27.1 & 27.8 & 16.2 & 38.1 & 13.3 & 23.8 & 80.0 & 40.0 & 28.9 & 26.3 \\
\hline$\geq 5$ & 28.2 & 16.7 & 18.8 & 44.5 & 60.0 & 59.3 & - & 40.0 & 38.8 & 33.9 \\
\hline Total & 100.0 & 100.0 & 100.0 & 100.0 & 100.0 & 100.0 & 100.0 & 100.0 & 100.0 & 100.0 \\
\hline
\end{tabular}

Table 8: Distribution of household heads raising pure hair goats according to their education level

\begin{tabular}{|c|c|c|c|c|c|c|c|c|c|c|}
\hline $\begin{array}{l}\text { Education } \\
\text { level }\end{array}$ & Aglasun & Altinyayla & Bucak & Cavdir & Celtikci & Golhisar & Karamanli & Kemer & Merkez & Tefenni \\
\hline $1^{\text {st level }}$ & 2.1 & - & 0.6 & - & - & - & - & - & - & 15.8 \\
\hline $2^{\text {nd }}$ level & - & - & 2.9 & - & - & - & - & - & 0.8 & 76.3 \\
\hline $3^{\text {rd }}$ level & 82.0 & 100.0 & 94.5 & 98.4 & 100.0 & 100.0 & 80.0 & 100.0 & 90.1 & 7.9 \\
\hline $4^{\text {tt level }}$ & 6.3 & - & 0.6 & 1.6 & - & - & - & - & 5.8 & - \\
\hline $5^{\text {tr level }}$ & 6.3 & - & 1.3 & - & - & - & 20.0 & - & 3.3 & - \\
\hline Total & 100.0 & 100.0 & 100.0 & 100.0 & 100.0 & 100.0 & 100.0 & 100.0 & 100.0 & 100.0 \\
\hline
\end{tabular}

household heads have to take care of in the municipal districts of Cavdir, Celtikci, Golhisar and Kemer is $45-60 \%$. Furthermore, the distribution of the education level of the subjects in the study area is shown in Table 8. The subjects have received their education in the period when basic education was 5 years in Turkey.

According to Table 8, except for the municipal district of Tefenni, the education level of the household heads in the other municipal districts is elementary school at a range of $80-100 \%$. However, $76 \%$ of the household heads are literate while $16 \%$ is illiterate in the municipal district of Tefenni.

The total annual income obtained from pure hair goats in the municipal districts is shown in Fig. 1 while per household average income has been shown in Fig. 2. In the assessment of Fig. 1 and 2, the municipal districts of Bucak and Tefenni attract attention in terms of the total income from pure hair goats while the municipal districts of Altinyayla, Cavdir, Merkez and Tefenni attract attention in terms of per household average income from pure hair goats. Similarly, the total and per household number of pure hair goats in the municipal districts are

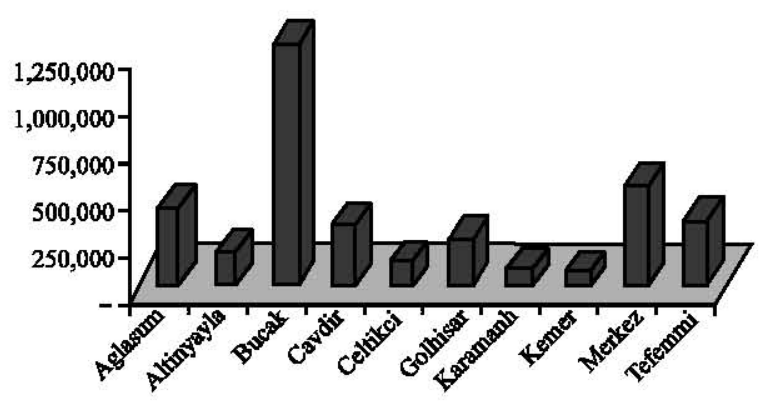

Fig. 2: Total income from pure hair goats

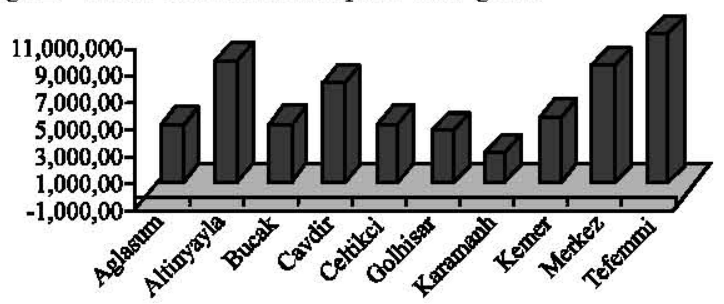

Fig. 3: Average income from pure hair goats

shown in Fig. 3 and 4. Although, the total number of pure hair goats in the municipal district of Bucak is the highest 


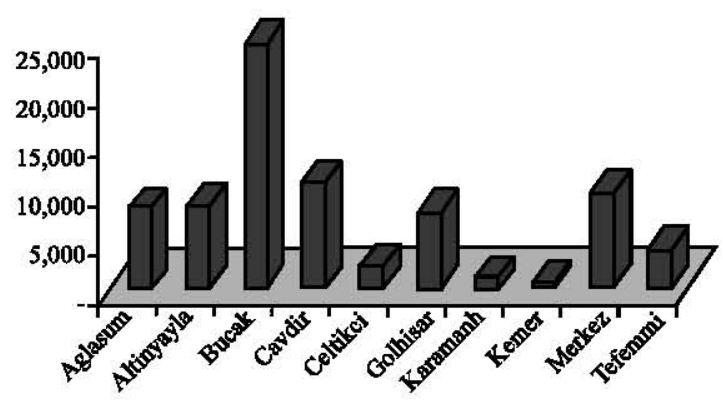

Fig. 4: Total number of pure hair goats

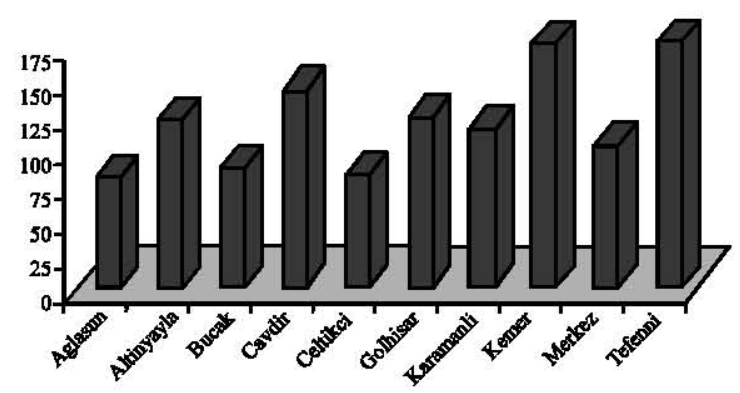

Fig. 5: Average number of pure hair goats

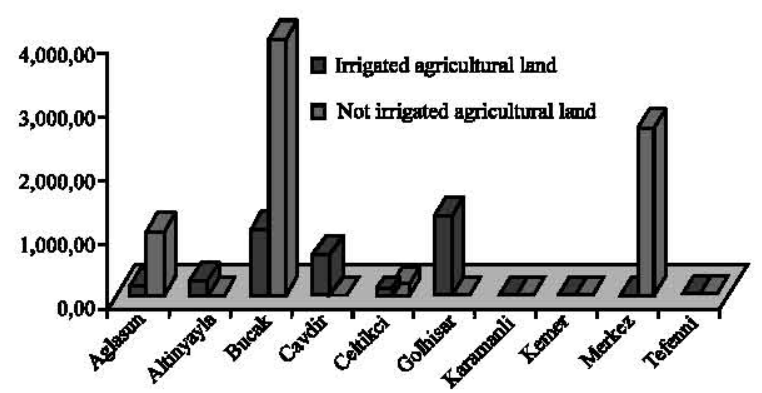

Fig. 6: Amount of total irrigated and dry agricultural land

level, per household number of pure hair goats is lower than the other municipal districts; There is a completely reverse trend in the municipal districts of Tefenni and Kemer (Fig. 3 and 4). The number of pure hair goats according to their gender is shown in Fig. 5. The general trend in the region is to raise 3-4 female pure hair goats per 1 male pure hair goat. However, this rate is 2 female pure hair goats per 1 male pure hair goat in the municipal district of Bucak.

The total amount of irrigated and dry agricultural land and per household irrigated and dry agricultural land are shown in Fig. 6 and 7. It is observed that the families raising pure hair goats in the municipal districts of Karamanli, Kemer and Tefenni have no land whereas they have irrigated agricultural land in the municipal districts of Altinyayla, Cavdir and Golhisar (Fig. 5).

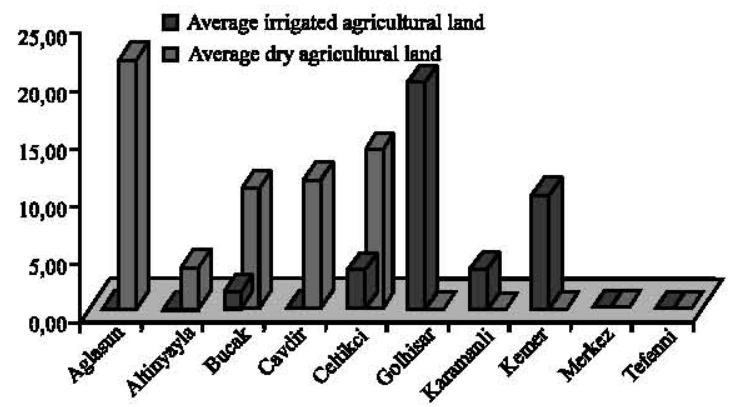

Fig. 7: Amount of irrigated and dry agricultural land per family head

The amount of land per family is $>5$ decares in the municipal districts of Aglasun, Bucak, Cavdir, Celtikci, Golhisar and Kemer (Fig. 6). The distributions according to the manner of utilizing goat milk in the research area are shown in Table 9. According to Table 9, 64-100\% of the families in the municipal districts of Bucak, Kemer and Merkez while $64-100 \%$ of the families in the municipal districts of Karamanli, Kemer and Merkez sell the milk without processing it. Information on whether the household is migrating in raising goats is shown in Table 10. On the other hand, the types of economic activities considered by families for using the public loan to be granted by GDF when renouncing to pure hair goat raising is shown in Table 11. In Table 11, it is demonstrated that $19-100 \%$ of the family heads in the municipal districts of Altinyayla, Bucak, Cav dir, Golhisar, Karamanli, Kemer and Tefenni have not applied for a loan and further, $9-74 \%$ of them have completely refused the types of public loans.

The persistence (determination) of the families in the research area to raise pure hair goats is shown in Table 12. In Table 12, the rate of families insisting to raise traditionally pure hair goats in the municipal districts of Altinyayla, Bucak, Cavdir, Golhisar, Karamanli and Tefenni ranges between 16-100\% while this rate ranges between $84-100 \%$ in the municipal districts of Aglasun, Bucak, Celtikci, Karamanli and Kemer.

There is no conformity among the family heads raising pure hair goats in the study area in terms of the number of pure hair goats raised and the income obtained from their goats and other economic activities. Yet, there is a conformity among the said family heads in terms of the number of dependent persons, level of education, land ownership, utilization of goat milk being a shepherd and the types of economic activities where they would like to use the public loan. However, this result is not consistent. This may be an indication of the fact that the subjects have not provided accurate information on the number of pure hair goats and the income they obtain. Because in 
Table 9: Manners in which families utilize goat milk

\begin{tabular}{|c|c|c|c|c|c|c|c|c|c|c|}
\hline $\begin{array}{l}\text { Manners of } \\
\text { utilizing } \\
\text { goat milk* }\end{array}$ & $\begin{array}{l}\text { Aglasun } \\
-\end{array}$ & Altinyayla & Bucak & Cavdir & Celtikci & $\begin{array}{l}\text { Golhisar } \\
\text { (\%) }- \text {--- }\end{array}$ & Karamanli & Kemer & Merkez & Tefenni \\
\hline 1 & 1.0 & - & 64.0 & - & - & 3.2 & - & 100.0 & 74.4 & - \\
\hline 2 & 99.0 & 100.0 & 6.8 & 100.0 & 100.0 & 96.8 & 100.0 & - & 25.6 & 100.0 \\
\hline 3 & - & - & 29.2 & - & - & - & - & - & - & - \\
\hline Total & 100.0 & 100.0 & 100.0 & 100.0 & 100.0 & 100.0 & 100.0 & 100.0 & 100.0 & 100.0 \\
\hline
\end{tabular}

*1:They utilize it themselves; 2 : They sell it; 3 : They utilize it themselves and also sell it

Table 10: Information on whether the families perform traditional migration in breeding goats

\begin{tabular}{lccccccccrr}
\hline $\begin{array}{l}\text { Status of } \\
\text { migration* }\end{array}$ & Aglasun & Altinyayla & Bucak & Cavdir & Celtikci & Golhisar & Karamanli & Kemer & Merkez & Tefenni \\
\hline 1 & 100.0 & 100.0 & 98.4 & - & 100.0 & 14.3 & - & - & 95.9 & - \\
2 & - & - & 1.6 & 100.0 & - & 85.7 & 100.0 & 100.0 & 4.1 & 100.0 \\
Total & 100.0 & 100.0 & 100.0 & 100.0 & 100.0 & 100.0 & 100.0 & 100.0 & 100.0 & 100.0 \\
\hline
\end{tabular}

*1:They do not migrate when raising goats 2 : They migrate when raising goats

Table 11: Distribution of the types of economic activities considered by families for using the public loan

\begin{tabular}{|c|c|c|c|c|c|c|c|c|c|c|}
\hline Type of & Aglasun & Altinyayla & Bucak & Cavdir & Celtikci & Golhisar & Karamanli & Kemer & Merkez & Tefenni \\
\hline loan* & & & & & & \%) ----- & - & 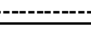 & 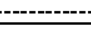 & - \\
\hline 1 & 68.8 & - & 54.9 & - & 93.3 & - & - & - & 45.5 & - \\
\hline 2 & 27.1 & - & 13.6 & - & - & - & - & - & 31.4 & - \\
\hline 3 & 3.1 & - & 2.9 & - & 6.7 & - & - & - & - & - \\
\hline 4 & 1.0 & - & 0.3 & - & - & - & - & - & - & - \\
\hline 5 & - & 38.9 & 19.2 & 100.0 & - & 52.4 & 100.0 & 40.0 & 23.1 & 26.3 \\
\hline 6 & - & 61.1 & 9.1 & - & - & 47.6 & - & 60.0 & - & 73.7 \\
\hline Total & 100.0 & 100.0 & 100.0 & 100.0 & 100.0 & 100.0 & 100.0 & 100.0 & 100.0 & 100.0 \\
\hline
\end{tabular}

*1: Bovine breeding; 2: Ovine breeding; 3: Greenhousing; 4:bApiculture; 5: Type of loan not specified; 6: Refuses the public loan

Table 12: Distribution of the persistence of families in raising pure hair goats

\begin{tabular}{|c|c|c|c|c|c|c|c|c|c|c|}
\hline $\begin{array}{l}\text { Persistence } \\
\text { in pure }\end{array}$ & Aglasun & Altinyayla & Bucak & Cavdir & Celtikci & Golhisar & Karamanli & Kemer & Merkez & Tefenni \\
\hline hair goats*" & & & & & & b) & & & & \\
\hline 1 & 2.1 & 62.5 & 15.9 & 100.0 & - & 76.2 & 100.0 & - & - & 100.0 \\
\hline 2 & 97.9 & 37.5 & 84.1 & - & 100.0 & 23.8 & - & 100.0 & 100.0 & - \\
\hline Total & 100.0 & 100.0 & 100.0 & 100.0 & 100.0 & 100.0 & 100.0 & 100.0 & 100.0 & 100.0 \\
\hline
\end{tabular}

*1: Persistent in raising pure hair goats; 2 : Not persistent in raising pure hair goats

the surveys, the subjects are reluctant to reply the questions on their income level, religious belief, the political party supported, use of alcohol-drugs due to various reasons or give unrealistic responses (Altunisik et al., 2005).

The same reason has led to the inability to determine the relation between the number of family members and the number of pure hair goats raised. Yet, as the number of family members in animal breeding which is a laborbased activity, the number of pure hair goats is expected to increase (Tolunay and Ayhan, 2010). But no significant relation is found between the number of pure hair goats raised and the income obtained from goats.

This result is conformant with literature (Kaymakci and Engindeniz, 2010; Ertin, 2010; Gulen, 1978). The main source of income for those living in this region is pure hair goats.

There is no relation between the number of pure hair goats raised and land ownership (Kaymakci and Engindeniz, 2010); however, a relation is detected between irrigated agricultural land and the pure hair goats raised in the municipal district of Golhisar. There is no relation between the number of pure hair goats raised and the persistence in raising pure hair goats. This result is conformant with literature. Because, the pure hair goat population raised in the region has dropped due to the goat policy pursued (Gulen, 1978; MEFT, 2008). It is observed that pure hair goat breeders mostly prefer to raise pure hair goats as they market the goat milk.

This result is conformant with literature (Ertin, 2010). Family members undertake the grazing of pure hair goats. Because the locals are poor (Gokce, 2010; Dellal, 2010; SPO. ,1996).

\section{CONCLUSION}

The municipal districts where the education level is low, there is no irrigated agricultural land owned and where there is dependence only on pure hair goats in terms of means of living are Altinyayla, Cavdir, Golhisar, Karamanli and Tefenni and they are persistent in raising pure hair goats. Therefore, they do not request a loan from the state for another type of economic activity and even reject the ones offered. For instance, the state has 
recommended breeders to raise Saanen goats instead of pure hair goats. The following statements of a pure hair goat breeder, stating; We have also bred Saanen goats as a family. But, the geographic and climactic structure of our region is not suitable for raising Saanen goats due to their physiological structure. We have quit because we were losing money. Now, we do not know what to do are thought-provoking and also reflect the desperateness experienced. This is a natural consequence of the ecological conditions of the region.

This study demonstrates that traditional pure hair goat raising will continue no matter what. As a result, preventing forest villagers from raising pure hair goats would be condemning them to hunger.

\section{ACKNOWLEDGEMENTS}

The data relating to the provinces of Burdur which were used in the statistical assessments by the researchers of this study have been procured from the Isparta Regional Directorate of Forestry. The researchers would like to extend their acknowledgment to the Deputy Regional Director of Forestry, Adnan Yilmazturk for his contribution and assistance.

\section{REFERENCES}

Altunisik, R., R. Coskun, S. Bayraktaroglu and E. Yildirim, 2005. Research Methods in Social Sciences-Applied SPSS. Sakarya Bookstore Publishing, Sakarya, pp: 359.

Avci, H., 2005. Forestry studies and pure hair goats. International Symposium on Forest-Goats-Erosion and Tourism, Adana.

Dellal, G., M. Ertugrul, N. Tekel and E. Pehlivan, 2010. Goat farming in Turkey in the Nagorno-forest areas: Current status and future. Proceedings of the Goat Keeping National Congress, June 24-26, Canakkale, pp: 42-60.

Ertek, T., 2008. Introduction to the Macro Economy. Istanbul, , pp: 428. ISBN: 9752958575.

Ertin, G., 2010. Agriculture-Animal Husbadry-Forestry. Anodulu Univ.

GDFVR, 2010. Provincial action plan (2008-2012). General Directorate of Forest and Village Relations. http://www.orkoy.gov.tr.

GFD, 1984. Regulation on Grazing of Animals in Forests and Meadows, Summer Pastures and Winter Quarters Located within Forests. General Directorate of Forestry, Ankara, pp: 40.
Geray, U. and S. Ozden, 2003. Silvopastoralism in Turkey's Mountainous Mediterranean Region. Mount. Res. Dev., 23: 128-131.

Gilmour, D.A. and R.J. Fisher, 1991. Villagers, Forests and Foresters. Sahayogi Press, Katmandu, Nepal, pp: 211-213.

Gokce, O., 2010. A assertion on harmonization of goatforest relations in Turkey. http://osmangokce.net/ kategori-tablosu/91-tuerkyede-kec-orman-lklernnuyumlulatirilmasi-uezerne-br-tez.

Gulen, I., 1978. Problem of Goat Grazing. Istanbul Univiersity, Istanbul, pp: 65-73.

Kaymakci, M. and S. Engindeniz, 2010. Goat keeping national congress. Preceedings, June 24-26, Canakkale, pp: 1-25.

MEFT, 2008. Action Plan for Reducing the Harms of Goats. Ministry Environment and Forestry of Turkey, Ankara, pp: 40.

Ocak, S., B. Bahadir and O. Guney, 2007. Traditional goat raising and rural development. Proceeding of 5 th National Congress on Animal Science, Sept. 5-8, Yuzuncu Yil University, Van, pp: 47-47.

Ozdamar, K., 2002. Paket Programlarý ile Istatistiksel Veri analizi-1. 4th Edn., Kaan Bookstore, PP: 686. Istanbul,ISBN: $975-6787-00-7 ; \quad$ 975-6787-01-5. http:/www.idefix.com/kitap/paket-programlar-ileistatistiks el-veri-analizi-1-kazim-ozdamar/tanim. asp?sid=XFDLW9JQQP2P3RVDZUAQ.

Ozder, M., 1997. Goat Raising. In: Goat Breeding, Ve Kaymakci M. and Y. Askin, Baran Publication, Izmir, Turkey, pp: 34-55.

SPO., 1996. Burdur Province Report. State Planning Organization, Ankara, pp: 104.

TSI, 2010. Turkish Statistical Institute. Statistical Indicators 1923-2008. Ankara. http://www.tuik. gov.tr/ yillik/Ist_gostergeler.pdf.

Tolunay, A. and V. Ayhan, 2010. Hair Goat breeding in Turkey in the present situation in utilization of forest resources. Proceedings of the Bottlenecks and Solutions In Goat Keeping National Congress, June 24-26, Canakkale, pp: 92-97.

Tolunay, A., V. Ayhan, D. Ince and A. Akyol, 2009. Traditional Usage of Kermes Oak Quercus coccifera L. and Pure Hair Goat Capra hircus L. in a Silvopastoral System on Davras Mountain in Anatolia: Constraints, Problems and Possibilities. J. Anim. Vet. Adv., 8: 1520-1526. 